\title{
Short Communication: A note on the new record of the amphibian fauna in Pulau Tinggi, Malaysia
}

\author{
NG YIN HUI ${ }^{1}$, EHWAN NGADI ${ }^{2}$, BADRUL MUNIR MD-ZAIN ${ }^{3}$, ZAINAL MD-ZAIRI ${ }^{4}$, \\ MUHAMMAD ABU BAKAR ABDUL-LATIFF ${ }^{1, \bullet}$ \\ ${ }^{1}$ Centre of Research for Sustainable Uses of Natural Resources, Faculty of Applied Sciences and Technology, Universiti Tun Hussein Onn Malaysia. \\ Pagoh Campus, KM1, Jalan Panchor, 84600 Muar, Johor, Malaysia. Tel.: +60-69742190, `email: latiff@uthm.edu.my, abdullatiff02727@ gmail.com \\ ${ }^{2}$ Kolej Genius Insan, Universiti Sains Islam Malaysia. Bandar Baru Nilai, 71800 Nilai, Negeri Sembilan, Malaysia \\ ${ }^{3}$ School of Environmental and Natural Resource Sciences, Faculty of Science and Technology, Universiti Kebangsaan Malaysia. 43600, Bangi, Selangor, \\ Malaysia \\ ${ }^{4}$ Shaz Resort Pulau Tinggi Sdn Bhd, Lot 44, Kampung Penaga, Pulau Tinggi, 86800 Mersing Johor, Malaysia
}

Manuscript received: 27 January 2020. Revision accepted: 11 May 2020.

\begin{abstract}
Ng} \mathrm{YH,} \mathrm{Ngadi} \mathrm{E,} \mathrm{Md-Zain} \mathrm{BM,} \mathrm{Md-Zairi} \mathrm{Z,} \mathrm{Abdul-Latiff} \mathrm{MAB.} \mathrm{2020.} \mathrm{A} \mathrm{note} \mathrm{on} \mathrm{the} \mathrm{new} \mathrm{record} \mathrm{of} \mathrm{the} \mathrm{amphibian} \mathrm{fauna} \mathrm{in}$ Pulau Tinggi, Malaysia. Biodiversitas 21: 2425-2429. A survey of amphibian species in Pulau Tinggi was conducted from February to October 2019. The study was carried out using the Visual Encounter Survey method and the drift-fenced pitfall trap method. Based on previously published literature and the present survey, an updated checklist of amphibians is presented. In total, nine species were recorded that comprise three previously recorded species (Limnonectes blythii, Polypedates leucomystax and Odorrana hosii), and six new recorded species (Limnonectes deinodon, Polypedates dischantus, Microhyla heymonsi, Fejervarya limnocharis, Ingerophrynus parvus, and Kaloula pulchra).
\end{abstract}

Keywords: Amphibian, animal, fauna, Pulau Tinggi, Seribuat Archipelago

\section{INTRODUCTION}

The Seribuat Archipelago located on the southeast coast of Peninsular Malaysia; it comprises 62 islands in the southern South China Sea. Pulau Tinggi is located in the middle arc of Seribuat Archipelago, which is located $12 \mathrm{~km}$ away from the inner arc. The island of the middle arc retains large areas of primary dipterocarp forest, lowland tropical forests, riparian vegetation, and mangroves which favor the habitat of amphibians (Grismer 2006). The weather of this island is hot and humid throughout the year (Department of Marine Park Malaysia 2012). The low logging activity preserves the inner part of the island and maintains the primary forest with diverse canopy. This island, with a total area of $17 \mathrm{~km}^{2}$, is one of the largest and tallest islands in the East Johor Island Archipelagos (EJIA). The land area in Pulau Tinggi covers approximately 1524.18 hectares (Department of Marine Park Malaysia 2012), and the elevation of the hills is more than 600 meters. The distance along the beach is $6 \mathrm{~km}$, and its width is $4 \mathrm{~km}$ (Fredolin et al. 2004). Pulau Tinggi was gazetted as a marine park in 1994 under the Malaysia Fishery Act (Department of Marine Park Malaysia 2012).

The research of biodiversity in the archipelago is important because of the high endemicity of species in the small area of the island (Fisher 2004). The first report of the herpetofauna in Pulau Tinggi has been done by Escobar et al. (2003a), and then followed by Grismer (2006) and Grismer (2011). The documentation of this unexplored island has generated the baseline data, and continuous monitoring is important to update the amphibian diversity in Pulau Tinggi. Based on the International Union for Conservation of Nature (IUCN) Red List in 2008, $42.5 \%$ of the amphibian species show population decrease, this led to the increasing number of threatened species. Less than $1 \%$ of species shows that population increases. Amphibians are diverse in the tropics, and the humid and hot environment of tropical rainforests and freshwater swamp forests in Malaysia are one of the hotspots for amphibians of approximately 300 species. Anurans can be found in the shallowest puddles, resting under leaf litter, making their foam nests in streamside vegetation, or calling continuously from tree holes.

Amphibian is a good biological indicator as they can only survive in a clean environment (Chan et al. 2010). Amphibians fauna are rarely recorded from sandy coastal habitats (Berry 1975; Daicus et al. 2010). Thus, a smaller number of amphibian studies had been conducted in coastal habitat. Therefore, most researchers neglected coastal ecosystems in studying the diversity of amphibians since it has a small number of species. On the other sites, herpetofauna studies also were conducted in the surrounding islands such as Pulau Tioman (Day 1990; Grismer 2011; Hendrickson 1966a,b; Lim and Lim 1999), Pulau Tulai (Hendrickson 1966a; Grismer et al. 2001b), Pulau Aur (Grismer et al. 2001a; Escobar et al. 2003b), and Pulau Pemanggil (Youmans et al. 2003). Therefore, this study was conducted in order to provide significant comparative data of amphibian species in Pulau Tinggi. 


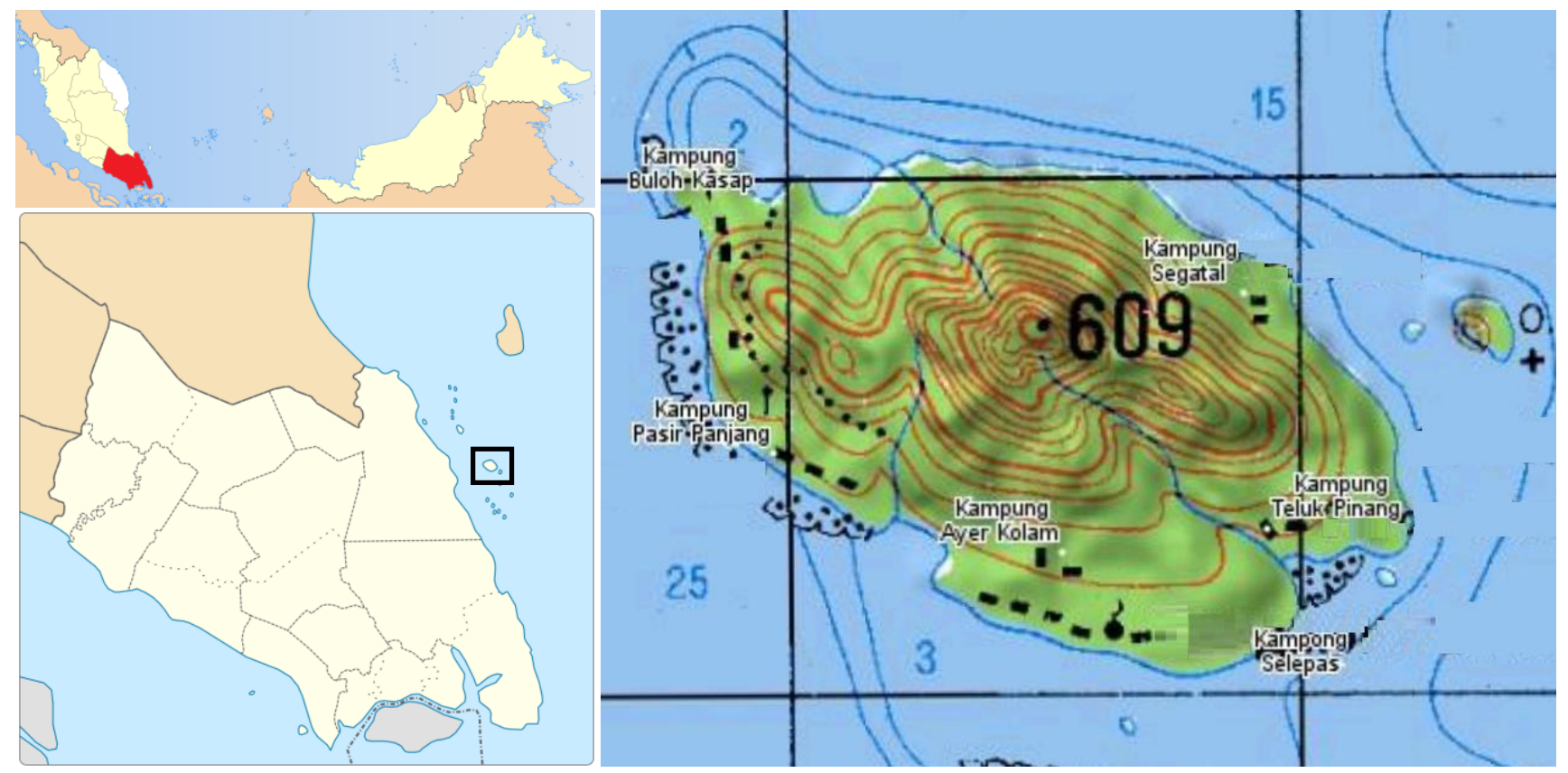

Figure 1. Map of Pulau Tinggi, Johor, Malaysia (modified using ATLOGIS Geoinformatics GmbH \& Co. KG application)

\section{MATERIALS AND METHODS}

Amphibian sampling was conducted at Pulau Tinggi, Malaysia from February until October 2019. It was carried out for ten days every month (Table S1). The samplings were majorly focused on the riverine area at Gunung Semudu and Kampung Sebirah. Two types of sampling were used; visual encounter survey (VES) and drift-fenced pitfall traps. The VES method is carried out by four to eight persons starting from 18.30 until 22.30 o'clock. The samples were collected bare-handed. The searching areas are focused on riverbanks, boulders, and forest trails. In order to maximize the data collection, the drift-fenced pitfall traps method was used. Figure 1 shows the island dissected by three main rivers up to the peak. These main rivers were expected to be the main hotspot for anurans. This method is comprised of orchid nets that act as a fence with $50 \mathrm{~cm}$ height and arranged in " $\mathrm{Y}$ " shape with $10 \mathrm{~m}$ long of each wing. At the center of the trap design, a 20L plastic bucket was buried with its mouth exposed, used to traps the anurans. Twenty traps were set up at four different sites along Gunung Semudu trails from Kampung Penaga.

Species encountered were photographed and collected, and their live colors and patterns were recorded directly. The specimens were euthanized using Tricaine solution (Ethyl 3-aminobenzoate methanesulfonate salt). The snoutvent length (SVL) and tibia length (TL) were measured and recorded. The muscle tissue was extracted and preserved in absolute alcohol for DNA analysis. The specimens are fixed in $10 \%$ formalin solution and soaked in $70 \%$ alcohol for long term preservation. All species were identified up to species level using keys following Frost et al. (2016). All specimens were deposited at the Wildlife Repository, Universiti Tun Hussein Onn Malaysia.

\section{RESULTS AND DISCUSSION}

Table 1 shows the amphibian species recorded in this study. A total of eight species of anurans were collected. One species belongs to the Bufonidae family which is Ingerophrynus parvus. Three species are of the Dicroglossidae family, which are Fejervarya limnocharis, Limnonectes blythii, and Limnonectes deinodon; two species are of Microhylidae, which are Kaloula pulchra and Microhyla heymonsi. Rhacophoridae family was presented by two species, which are Polypedates leucomystax and Polypedates discantus

\section{Species notes \\ Ingerophrynus parvus Boulenger, 1887}

Lesser Malacca Toad

This species was collected from the sandy soil around the Shaz Resort. This species was resting during the capture.

\section{Fejervarya limnocharis Gravenhorst, 1829}

Asian grass frog

One sample of this species was collected on the grass near the Shaz Resort. The distance between this species and the shoreline is approximately $20 \mathrm{~m}$.

\section{Limnonectus deinodon Dehling, 2014}

Flat-headed corrugated frog

The species was found congregated abundantly at the riverbank in the forest area; $\mathrm{N} 02^{\circ} 17^{\prime} 31.1^{\prime \prime}$, E 104'07'36.0' (142 m); February 23, 2019, UTHM 0016A: an adult female. 
Table 1. Amphibian species found in Pulau Tinggi in 2019

\begin{tabular}{llll}
\hline Family & Species & Common name & IUCN Status \\
\hline Bufonidae & Ingerophrynus parvus Bioulenger, 1887 & Lesser Malacca Toad & LC \\
Dicroglossidae & Fejervarya limnocharis Gravenhorst, 1829 & Asian grass frog & LC \\
& Limnonectes deinodon Dehling, 2014 & Flat-headed corrugated frog & DD \\
& Limnonectes blythii Boulenger, 1920 & Giant frog & NT \\
Microhylidae & Kaloula pulchra Gray, 1831 & Banded bullfrog & LC \\
& Microhyla heymonsi Vogt, 1911 & Dark-sided Chorus Frog & LC \\
Rhacophoridae & Polypedates leucomystax Gravenhorst, 1829 & Four-lined tree frog & LC \\
& Polypedates discantus Rujirawan, Stuart \& Aowphol, 2013 & Malayan slender tree fog & NA \\
\hline
\end{tabular}

Note: NA: not available, DD: data deficient, LC: least concern, NT: near threatened

Table 2. List of amphibian species found in Pulau Tinggi

\begin{tabular}{|c|c|c|c|c|c|}
\hline Family & Species & Escobar 2003b & Grismer 2006 & Grismer 2011 & This study \\
\hline Bufonidae & Ingerophrynus parvus & & & & + \\
\hline \multirow[t]{3}{*}{ Dicroglossidae } & Fejervarya limnocharis & & & & + \\
\hline & Limnonectes deinodon & & & & + \\
\hline & Limnonectes blythii & + & + & + & + \\
\hline \multirow[t]{2}{*}{ Microhylidae } & Kaloula pulchra & & & & + \\
\hline & Microhyla heymonsi & & & & + \\
\hline Ranidae & Odorrana hosii & + & + & + & \\
\hline \multirow[t]{2}{*}{ Rhacophoridae } & Polypedates leucomystax & + & & + & + \\
\hline & Polypedates discantus & & & & + \\
\hline
\end{tabular}

Note: + : present

\section{Limnonectes blythii Boulenger, 1920}

Asian giant frog

In the forest area; N $02^{\circ} 17^{\prime} 29.1^{\prime \prime}, \mathrm{E} 104^{\circ} 07^{\prime} 25.7^{\prime \prime}$ (82m); August 31, 2019, PT0022A: an adult male.

\section{Kaloula pulchra Gray, 1831}

Malaysian bullfrog/painted burrowing frog

On dry sandy soil; N $02^{\circ} 17^{\prime} 12.1^{\prime \prime}$, E $104^{\circ} 07^{\prime} 16.8^{\prime \prime}$ (7 m); July 16, 2019; PT0010A: an adult female found resting on weeds. We frequently heard the advertisement call and have a high chance to be seen around Shaz resort.

\section{Microhyla heymonsi Vogt, 1911}

This species was observed near the puddle. It's clear calling sound indicates the presence of the species. However, its tiny size makes it difficult for the observant to find the individuals.

\section{Polypedates leucomystax Gravnernhost, 1829}

Four-lined treefrog/common treefrog

On dry sandy shore; N 02 $177^{\prime} 27.0^{\prime \prime}$, E $104^{\circ} 07^{\prime} 18.7^{\prime \prime}$ (85 m); August 30, 2019, PT0021A: an adult female, fourlined stripes on dorsum.

\section{Polypedates discantus Rujirawan, Stuart \& Auwphol, 2013}

Malayan slender tree frog

On the forest floor around resort area; $\mathrm{N} \mathrm{02}{ }^{\circ} 17^{\prime 2} 25.7^{\prime \prime}, \mathrm{E}$ 10407'17.3" (82 m); August 31, 2019, PT0024A: an adult female, small black dot present on dorsum.
The latest study has recorded the additional number of amphibian species at Pulau Tinggi, whereas the previous report has not. Escobar et al. (2003b) reported three species, namely L. blythii, P. leucomystax and $O$. hosii, and the following field survey by Grismer (2006) found two species, which are L. blythii and $O$. hosii. In the book "Amphibians and Reptiles of the Seribuat Archipelago Peninsula Malaysia", Grismer (2011) recorded three species of amphibians namely L. blythii, P. leucomystax and $O$. hosii. The six new recorded species in this study comprise $L$. deinodon, $P$. dischantus, $M$. heymonsi, $F$. limnocharis, I. parvus, and K. pulchra (Table 2).

In the present study, six new species were recorded, adding the species number, thus totaling to nine. It shows that the area of Pulau Tinggi is still harboring a number of species that had not been discovered yet. It also indicates that the information on amphibian species in Pulau Tinggi is still not enough. It might be due to several limitations such as landscape and topography. The hilly area and steep slope limit the researcher to explore the area. Furthermore, the forest landscape also limits the exploration of the species that complicates the researcher to conduct sampling. The island ecosystems that had a smaller number of permanent water body (rivers, cascades, waterfall and small streams) (Escobar et al. 2003b), makes the exploration becomes more difficult because of the few habitats. Amphibian species tend to become very dependent on the water body, thus, the searching areas should be focusing on the water body (Grismer 2006). However, a low number of amphibian species reflect that 
the island ecosystems are harboring few numbers of amphibian species. This is because, this isolated ecosystem inhibits the dispersion of amphibian species since the island is surrounded by sea-water, which restricted their movements to the other islands (Grismer 2006).

In conclusion, the new record of species shows an extensive study needed to be conducted on this island. The study of amphibian diversity on the surrounding island is also needed to fill the knowledge gap of biodiversity in the Seribuat Archipelago. More new species are expected to be found in future studies. Increasing awareness in conservation of amphibians is important as it is one of the most threatened classes of vertebrates, especially in the insular ecosystem.

\section{ACKNOWLEDGEMENTS}

We are deeply indebted to the Department of Wildlife and National Parks Malaysia that provided us with the necessary assistance and permission for this research (JPHL \& TN (IP): 600-6/1/4 (03)). The authors acknowledge Universiti Tun Hussein Onn Malaysia and Shaz Resort for providing the necessary funding, facilities, and assistance. This research was supported by Malaysian Technical University Network Grant (UTHM-MTUNK121) under the Ministry of Education Malaysia, Industrial Grant, by Shaz Resort Sdn Bhd (UTHM-SHAZ-M004) and GPPS-UTHM-2018-H288 postgraduate grant by Universiti Tun Hussein Onn Malaysia (UTHM), Malaysia.

\section{REFERENCES}

Berry PY. 1975. The Amphibian Fauna of Peninsular Malaysia. Tropical Press, Kuala Lumpur.

Chan KO, Daicus B, Norhayati A. 2010. A revised checklist of the amphibians of Peninsular Malaysia. Russ J Herpetol 17 (3): 202-206.

Daicus B, Rosli H, Yong HS, Siti ZMD, Norhayati A, Lim Boo Liat. 2010. A note on the amphibian fauna at Pantai Melawi Bachok, Kelantan. Malaysian J Sci 29: 111-115.

Day M. 1990. Zoological research. University of Bristol, Tioman Archipelago Expedition, Peninsular Malaysia, 1988. Final reportUniversity of Bristol, UK.
Department of Marine Park Malaysia. 2012. Pulau Tinggi and Pulau Sibu Marine Park Management Plan, Department of Marine Park Malaysia, Kuala Lumpur.

Escobar RA, Castro J, Morgan D, Hover SM, Szutz TR, Mccloskey K, Rickgregory R. 2003b. Additions to the herpetofauna of Pulau Aur, Johor, West Malaysia. Hamadryad 27: 287-288.

Escobar RA, Grismer JL, Youmans TM, Wood PL, Kendall JRSD, Castro J, Magil T, Rasmussen C, Szutz TR, Hover SM, Morgan D, Raynor C, Mccloskey K, Izvernari N, Hunter A, Bernard JM, Hinojosa N, Dyer T, Anlauf J, Martinez J, Andreiko S, Gregory R, Yeen LS, Wuertz W, Kaiser H, Grismer LL. 2003a. First report on the herpetofauna of Pulau Tinggi, Johor, West Malaysia. Hamadryad 27: 259-262.

Fisher E. 2004. Island ecosystems conservation and sustainable use: problems and challenges. Insula 9-14.

Fredolin TT, Syamil MY, Liew J. 2004. Circulation Pattern and Thermohaline Structures of Waters off Pulau Tinggi, Johor. Marine Science Program. School of Environmental and Natural Resource Sciences, Faculty of Science and Technology, Universiti Kebangsaan Malaysia, Kuala Lumpur.

Frost DR. 2016: Amphibian Species of the World: An Online Reference. Version 6.0. Electronic Database. American Museum of Natural History, New York.

Grismer LL, Yaakob NS, Lim BL, Leong TM, Das I, Sosa RA, Grismer JL, Crane KM, Diaz RE, Figueroa SV, Ledbetter CA, Newbold SC, Newbold SR, Payel CP, Castro J, Escobar RA, Guerrero S, Pinedo JW, Jones PA, Kaiser H. 2001a. First report on the herpetofauna of Pulau Aur, Johor, West Malaysia. Hamadryad 26 (2): 350-353.

Grismer LL, Yaakob NS, Lim BL, Leong TM, Das I, Sosa RA, Grismer JL, Crane KM, Diaz RE, Figueroa SV, Ledbetter CA, Newbold SC, Newbold SR, Payel CP, Castro J, Escobar RA, Guerrero S, Pinedo JW, Jones PA, Kaiser H. 2001b. Report on the herpetofauna of Pulau Tulai, West Malaysia. Hamadryad 26 (2): 364-371.

Grismer LL, Youmans TM, Wood PL, Grismer JL. 2006. Checklist of The Herpetofauna of The Seribuat Archipelago, West Malaysia With Comments on Biogeography, Natural History, and Adaptive Types. Raffles B Zool 54 (1): 157-180.

Grismer LL. 2011. Amphibians and Reptiles of the Seribuat Archipelago, Peninsula Malaysia. Edition Chimaira, Frankfurt am Main.

Hendrickson JR. 1966a. Observations on the fauna of Pulau Tioman and Pulau Tulai. 5. The reptiles. Bull Natl Mus Sing 34: 53-71.

Hendrickson JR. 1966b. Observations on the fauna of Pulau Tioman and Pulau Tulai. 6. The amphibians. Bull Natl Mus Singap 34: 72-84.

IUCN Red List 2008. The IUCN Amphibians Initiative: A record of the 2001-2008 amphibian assessment efforts for the IUCN Red List. IUCN, Gland.

Lim KKKP, Lim LJ. 1999. The terrestrial herpetofauna of Pulau Tioman, Peninsular Malaysia. Raffles Bull Zool 6: 131-155.

Youmans TM, Grismer JL, Escobar III RA, Johnson R, Grismer LL. 2003. First report on herpetofauna of Pulau Pemanggil, Johor, West Malaysia. Hamadryad 27: 148-149. 
Table S1. List of amphibians recorded in Pulau Tinggi, Johor, Malaysia (February-October 2019)

\begin{tabular}{|c|c|c|c|c|c|}
\hline \multirow{2}{*}{ Date } & \multirow{2}{*}{ Species } & \multirow{2}{*}{ Tag No. } & \multicolumn{2}{|l|}{ Measurement } & \multirow{2}{*}{ Gender } \\
\hline & & & Snouth-vent length & Tibia & \\
\hline 21-Feb-19 & Polypedates discantus & UTHM 0001A & 64.6 & 32.6 & $\mathrm{~F}$ \\
\hline 21-Feb-19 & Polypedates discantus & UTHM 0002A & 45 & 24.4 & M \\
\hline 21-Feb-19 & Polypedates discantus & UTHM 0003A & 48.5 & 26.6 & M \\
\hline 21-Feb-19 & Polypedates discantus & UTHM 0004A & 46.1 & 26.1 & $\mathrm{M}$ \\
\hline 21-Feb-19 & Polypedates leucomystax & UTHM 0005A & 41.1 & 23 & M \\
\hline 21-Feb-19 & Polypedates discantus & UTHM 0006A & 47.1 & 27.7 & M \\
\hline 21-Feb-19 & Polypedates leucomystax & UTHM 0007A & 51.8 & 28.4 & M \\
\hline 21-Feb-19 & Polypedates leucomystax & UTHM 0008A & 50.3 & 30.4 & M \\
\hline 21-Feb-19 & Polypedates leucomystax & UTHM 0009A & 51.15 & 28.5 & M \\
\hline 21-Feb-19 & Polypedates leucomystax & UTHM 0010A & 51.4 & 29 & M \\
\hline 22-Feb-19 & Polypedates discantus & UTHM 0011A & 51.55 & 28.5 & M \\
\hline 22-Feb-19 & Kaloula pulchra & UTHM 0012A & 40 & 15.95 & $\mathrm{~F}$ \\
\hline 22-Feb-19 & Limnonectes blythii & UTHM 0013A & 95.3 & 56 & $\mathrm{~F}$ \\
\hline 22-Feb-19 & Polypedates discantus & UTHM 0014A & 46.1 & 25.5 & $\mathrm{~F}$ \\
\hline 22-Feb-19 & Polypedates discantus & UTHM 0015A & 45.5 & 23.5 & M \\
\hline 22-Feb-19 & Limnonectes deionodon & UTHM 0016A & 38.1 & 20 & $\mathrm{~F}$ \\
\hline 22-Feb-19 & Polypedates discantus & UTHM 0017A & & & \\
\hline 23-Feb-19 & Polypedates discantus & UTHM 0018A & & & \\
\hline 23-Feb-19 & Limnonectes blythii & UTHM 0019A & & & \\
\hline 23-Feb-19 & Limnonectes blythii & UTHM 0020A & & & \\
\hline 23-Feb-19 & Kaloula pulchra & UTHM 0021A & & & \\
\hline 23-Feb-19 & Kaloula pulchra & UTHM 0022A & & & \\
\hline 23-Feb-19 & Microhyla heymonsi & & & & \\
\hline 23-Feb-19 & Ingerophrynus parvus & & & & \\
\hline 23-Apr-19 & Polypedates leucomystax & UTHM 0023A & 3.6 & 1.8 & $\mathrm{~F}$ \\
\hline 20-Apr-19 & Kaloula pulchra & PT 0001A & 6 & 2 & \\
\hline 16-Jul-19 & Kaloula pulchra & PT 0002A & 7.5 & 2 & \\
\hline 16-Jul-19 & Kaloula pulchra & PT 0003A & 7 & 2.3 & \\
\hline 16-Jul-19 & Kaloula pulchra & PT 0004A & 7 & 2 & \\
\hline 16-Jul-19 & Kaloula pulchra & PT 0005A & 7.5 & 2.2 & \\
\hline 16-Jul-19 & Kaloula pulchra & PT 0006A & 7 & 1.5 & \\
\hline 16-Jul-19 & Kaloula pulchra & PT 0007A & 7 & 1.8 & \\
\hline 16-Jul-19 & Kaloula pulchra & PT 0008A & 7 & 1.5 & \\
\hline 16-Jul-19 & Kaloula pulchra & PT 0009A & 6.8 & 1.8 & \\
\hline 16-Jul-19 & Kaloula pulchra & PT 0010A & 7 & 2 & \\
\hline 16-Jul-19 & Kaloula pulchra & PT 0011A & 6.5 & 1.2 & \\
\hline 29-Aug-19 & Polypedates discantus & PT 0012A & 6.5 & 3.5 & $\mathrm{~F}$ \\
\hline 29-Aug-19 & Polypedates discantus & PT 0013A & 5.3 & 3 & M \\
\hline 29-Aug-19 & Polypedates discantus & PT 0014A & 7 & 3.5 & $\mathrm{~F}$ \\
\hline 29-Aug-19 & Polypedates discantus & PT 0015A & 4.8 & 2.5 & M \\
\hline 29-Aug-19 & Polypedates discantus & PT 0016A & 5.5 & 2.8 & M \\
\hline 29-Aug-19 & Polypedates discantus & PT 0017A & 5 & 2.2 & $\mathrm{~F}$ \\
\hline 30-Aug-19 & Linonectes blythii & PT 0018A & 7.8 & 4 & $\mathrm{~F}$ \\
\hline 30-Aug-19 & Limnonectes blythii & PT 0019A & 6.8 & 3.5 & M \\
\hline 30-Aug-19 & Polypedates discantus & PT 0020A & 6.8 & 3.5 & $\mathrm{~F}$ \\
\hline 30-Aug-19 & Polypedates leucomystax & PT 0021A & 7.2 & 3.6 & $\mathrm{~F}$ \\
\hline 31-Aug-19 & Limnonectes blythii & PT 0022A & 8.7 & 4.4 & M \\
\hline 31-Aug-19 & Polypedates discantus & PT 0023A & 4.7 & 2.5 & $\mathrm{~F}$ \\
\hline 31-Aug-19 & Polypedates discantus & PT 0024A & 7 & 3.3 & $\mathrm{~F}$ \\
\hline 31-Aug-19 & Limnonectes blythii & PT 0025A & 3 & 2 & M \\
\hline 31-Aug-19 & Limnonectes blythii & PT 0026A & 8.6 & 3.9 & $\mathrm{~F}$ \\
\hline 31-Aug-19 & Limnonectes blythii & PT 0027A & 5.7 & 2.8 & \\
\hline 5-Oct-19 & Limnonectes blythii & PT 0028A & 4.3 & 2 & \\
\hline 5-Oct-19 & Limnonectes blythii & PT 0029A & 7.2 & 3.5 & \\
\hline 5-Oct-19 & Polypedates leucomystax & PT 0030A & 4.7 & 2.8 & \\
\hline 5-Oct-19 & Limnonectes blythii & PT 0031A & 3.2 & 1.5 & \\
\hline 5-Oct-19 & Polypedates discantus & PT 0032A & 4.7 & 2.2 & \\
\hline
\end{tabular}

